\title{
Predict Risk Factors of Preeclampsia Among Pregnant Women Attended Antenatal Clinic at Assiut University Hospital
}

\author{
Elham M. Ahmed ${ }^{1}$, Rabaa H. Hassanen ${ }^{2}$, Ahmed M Abbas ${ }^{3}$ \& Shaimaa A. Kalaf ${ }^{4}$. \\ 1. Nursing specialist, Faculty of Medicine and Health Sciences, Hodeida University- Yemen. \\ 2. Assistant Prof of Community Health Nursing Department, Faculty of Nursing, Assiut University, Egypt. \\ 3. Lecturer of Obstetrics and gynecology Medicine Department, Faculty of Medicine, Assiut University, Egypt. \\ 4. Lecturer of Community Health Nursing Department, Faculty of Nursing, Assiut University, Egypt.
}

\begin{abstract}
Background: Preeclampsia results in a high risk of morbidity and mortality of mother and fetus in the world. This study aimed to Predict Risk Factors of Preeclampsia aqmong pregnant women attended Antenatal Clinic at Assiut University Hospital. Subjects and methods; A cross sectional-cohort descriptive study design was utilized. 230 pregnant women convenience sampling attended during the period of the study (six months). Two tools were used: Tool (1): interview questionnaire sheet included three parts, the first one: socioeconomic scale, the second part: family history risk factors, and the Third part is maternal medical, gynecological and obstetric history. Tool (2): Physical examination of the pregnant women (BP, edema, urine analysis weight and Hight). Three follow-up physical examinations were done. Results: More than two fifths of the pregnant women's age from 25-30 years old. Cases diagnosed with PE during all the follow up are $16.1 \%$ of studied sample. There was a significant relation between (body mass index and history of previous preeclampsia) and development of preeclampsia ( $\mathrm{p}$-value $=0.000$ and 0.000 respectively). Conclusions: History of DM and hypertension were the most risk factors predictors in preeclampsia among pregnant women. Recommendations: Health education for pregnant women about risk factors of PE during premarital examination early antenatal booking.
\end{abstract}

Keywords: Prediction, Preeclampsia \& Risk Factors.

\section{Introduction}

Pre-eclampsia (PE) is a disorder of pregnancy characterized by high blood pressure and a large amount of protein in the urine, it may result in seizures at which point it is known as eclampsia (Sidani \& Siddik, 2011, American College of Obstetricians \& Gynecologists (ACOG), 2013 \& Al-Jameil et al, 2014) It has a significant public health threat in both developed and developing countries contributing to maternal and perinatal morbidity and mortality globally. However, the impact of the disease is felt more severely in developing countries (Osungbade \& Ige, 2011).

The diagnostic criteria for PE are a systolic blood pressure $\geq 140 \mathrm{~mm} \mathrm{Hg}$ or diastolic blood pressure $\geq$ $90 \mathrm{~mm} \mathrm{Hg}$ on 2 occasions at least 4 hrs. Apart after 20 weeks gestation in women with a previously normal blood pressure and proteinuria $\geq 300 \mathrm{mg} / 24$ hrs. or a protein/creatinine ratio $\geq 0.3 \mathrm{mg} / \mathrm{dL}$ (ACOG, 2013). But these signs may also be accompanied by elevated serum creatinine levels, decreased platelet count of $<100,000 / \mathrm{mm}$ (Al-Jameil et al., 2014)., microangiogenic hemolysis, elevated alanine aminotransferase or aspartate aminotransferase, persistent headache or other cerebral or visual disturbances, or persistent epigastric pain (Brown et al., 2013).

World Health Organization (WHO) estimates the incidence of PE to be seven times higher in developing countries (2.8\% of live births) than in developed countries $(0.4 \%)$ which is due to poor health seeking behaviors and unavailability of health care facilities and personnel (WHO, 2005, Abubakar et al, 2009 \& Munirathnamma \& Lakshmamma, 2013).

$\mathrm{PE}$ affects $3 \%-8 \%$ of pregnancies worldwide and is among the hypertensive disorders contributing to maternal mortality. Worldwide estimated that 5, 00,000 or more women die each year from complications of pregnancy and $95 \%$ of these women are in Africa and Asia, PE and eclampsia together, affect about $10 \%$ of all pregnant women around the world(Khanum et al., 2015 \& Thadhani et al., 2016).

In Egypt, the prevalence of PE is (10.7\%) in a community-based study, while in hospital-based studies it ranged from (9.1-12.5\%) of all deliveries (Kharaghani et al., 2016).

Women identified as high-risk can be scheduled for more intensive antenatal surveillance and prophylactic interventions. Current strategies for risk assessment are based on the obstetric and medical history and clinical examination (Brice et al., 2009, Poon et al, 2010 \& North et al., 2011).

Several prediction models have shown the value of using blood pressure recorded at the first visit to the antenatal clinic alongside other maternal characteristics to predict the later development of 
pre-eclampsia(North et al., 2011, Kenny et al., 2014) Pregnant women should be made aware of the need to seek immediate advice from a health care professional if they experience symptoms of PE, which include: severe headache, problems with vision, such as blurring or flashing before the eyes, severe pain just below the ribs, vomiting and sudden swelling of the face, hands or feet (National Institute for Health \& Clinical Excellence, 2012).

The major value of prevention is to identify women at high risk of $\mathrm{PE}$ and to make a medical intervention so that the disorder never occurs or is postponed (Jasovic, 2013).

The nurse plays role in prevention PE through health education of pregnant women about healthy diet and lifestyle modifications (Hofmeyr et al., 2014 \& Salam et al., 2015).

\section{Significance of the study}

PE contributes to a very high percentage of maternal and fetal mortality and morbidity rates in Egypt and worldwide. Till this moment, the exact cause of PE is unknown and there is no definite method for prediction of PE to avoid it, but multiple clinical risk factors are suggested to cause the development of this disease. So this study will develop a score for predicting the probability of developing preeclampsia during early pregnancy, which will help in decreasing the maternal mortality and morbidity rates and it would enable discovering an effective and a definite preventive method for PE through future studies (Gaccioli et al., 2017).

\section{This study Aimed to}

Predict risk factors of preeclampsia among pregnant women attended Antenatal Clinic at Assiut

University Hospital.

\section{Research questions}

- What are the risk factors of PE detecting through follow-up stages?

- What are the incidences of PE among studied pregnant women in Assiut University Women Health Hospital?

- Is there a relation between socio-demographic characteristics and developing PE?

- Is there a relation between medical and obstetrical history and developing PE?

\section{Subjects and Methods}

A Cross sectional-cohort descriptive research design was used.

Setting: The present study was conducted in Antenatal Care Clinic (ANC) at Assiut University Women Health Hospital. This clinic is the main largest clinic in Assiut Governorate which provides antenatal care services for the pregnant women.
Sampling and sample size: A convenience sampling of pregnant women who attended at ANC during six months, period from the beginning of May 2016 till the end of December 2016 and follow up ended at (March 2017). The total number of study sample composed of 230 pregnant women was included and continued until the end of the study.

Inclusion criteria All pregnant women who agree to participate in the study were included if gestational age was from $4^{\text {th }}$ to $18^{\text {th }}$ weeks and without mental disorders.

Two tools were utilized in the current study: Tool (1) Structured interview questionnaire was developed after reviewing the relevant literature (Essam et al, 2011, Seed et al, 2011, Direkvand-Moghadam et al, 2012, Guerrier et al, 2013 \& Poon and Nicolaides, 2014), it included three parts: -

Part (1) Socio demographic scale (Abd El-twab A., 2012) as Age, name, telephone number, level of education, occupation, degree of consanguinity..........etc.

Scoring system of socioeconomic scale:

-High socioeconomic class scores are more than 103. -Middle socioeconomic class scores range between 58 and 103.

-Low socioeconomic class scores are less than 58.

Part (2) Family history of risk factors for PE such as: Previous PE in family, history of diabetes mellitus, chronic hypertension, chronic kidney disease, cardiovascular diseases........etc.

Part (3) Medical and obstetric history such as: Gestational age at the beginning of the current study, order of pregnancy, number of parity, history of preeclampsia, hypertension, diabetes mellitus and outcome of the present pregnancy.......etc.

Tool (2): Physical examination of the pregnant women including: blood pressure, weight, height, signs of edema and urine analysis used during first contact with woman in clinic (4 to18) weeks of gestation.

Validity of sheet: This sheet was reviewed by ( 5 experts), from community health nursing and obstetrical and gynecological nursing staff in Assiut University to assess and evaluate the sheet items to secure the validity of this sheet. Modifications were done according to the directions of the experts committee.

Reliability: Reliability was analyzed by Cronbach's alpha the value was 0.823 .

\section{A pilot study}

was carried out on (10\%) of the pregnant women for testing the feasibility, clarity and to estimate the required time to fill the questionnaire sheet. The necessary modifications were done to reach the final form. This number was excluded from the total 
number of the sample size because done modification of questionnaire sheet.

Data collection: An official approval letter was obtained from the Dean of Faculty of Nursing, Assiut University to the Director of Assiut University Women Health Hospital; this letter included a brief explanation of the objectives and a permission to carry out the study.

The study started in 24 of May 2016 and ended in 24 of December 2016; data were collected from the ANC for six months (from the beginning of May 2016 to December/2016) and the follow up ended in March 2017. The researchers collected data 3 days per week $\backslash 4$ hours from 9 am to 1 pm each day. Almost (3:4) woman were interviewed per day and oral agreement was obtained from them after explaining the aim of the study. The researchers selected pregnant women who fulfilled and meet the criteria and explained the nature of the study to each participant who agreed to participate in this study. Each participant was individually interviewed in the examination room in the ANC in order to collect the data and physical examination for pregnant women (BP, edema, urine analysis and weight, height) was done. The average time taken for completing each questionnaire sheet was around 30 minutes or more depending on the response of each participant.

Follow up the pregnant women through telephone calling three times after the first contact as the following:

$\mathbf{1}^{\text {st }}$ follow up: At the $\left(24^{\text {th }}\right)$ weeks of gestation, the pregnant women conducted phone calling to know result of (blood pressure, urine analysis and signs of edema) and know if she diagnosed with PE or not by physician. If the pregnant woman is diagnosed with $\mathrm{PE}$, she will not be followed through second follow up.

$2^{\text {nd }}$ follow up: Before the $\left(32^{\text {nd }}\right)$ weeks of gestation, the pregnant women conducted phone calling to know result of (blood pressure, urine analysis and signs of edema) and know if she is diagnosed with PE or not by the physician. If the pregnant woman is diagnosed with PE, she will not be followed through third follow up.

$\mathbf{3}^{\text {rd }}$ follow up: After $\left(32^{\text {nd }}\right)$ weeks, the pregnant women conducted phone calling to know the result of (blood pressure, urine analysis and signs of edema) and to know if she diagnosed with PE or not by the physician. Then, data about pregnancy out-comes will be collected. If she deliveries: gestational age at delivery, mode of delivery, fetus status, fetus weight, fetus chronological age at birth, fetus gender and post-partum eclampsia.

\section{Ethical consideration}

The study proposal was approved by the investigator and ethics committee in the Faculty of Nursing,
Assiut University. Participants in the study were informed about their rights to refuse or consent participation in the study. The investigator also reassured the participants in the study that their privacy would be protected and any obtained information would be strictly confidential before starting data collection.

\section{Statistical design}

The collected data were coded, categorized, analyzed and tabulated. Data analysis was done using STATA version 12 and SPSS (Statistical Package for Social Science) version 19. Data were presented as number, percentage, mean and standard deviation.

Chi-square and Fisher Exact Tests were used to compare between qualitative variables.

Mann-Whitney test was used to compare quantitative variables between groups in case of nonparametric data. A regression analysis was done to rank the different risk factors of preeclampsia. Pvalue is considered statistically significant when $\mathbf{P}<$ 0.05.

Limitations of the study: Calling the pregnant women many times to complete the follow up stage. 


\section{Results}

Table (1): Sociodemographic data of studied pregnant women.

\begin{tabular}{|c|c|c|}
\hline Items & No. $(n=230)$ & $\%$ \\
\hline $\begin{array}{l}20<25 \text { years } \\
25<30 \text { years } \\
>30 \text { years } \\
\text { Mean } \pm \text { SD }(\text { Range })\end{array}$ & $\begin{array}{r}77 \\
94 \\
59 \\
27.47 \pm 5.65(17.0-42.0)\end{array}$ & $\begin{array}{l}33.5 \\
40.9 \\
25.6\end{array}$ \\
\hline $\begin{array}{l}\text { Residence: } \\
\text { Rural } \\
\text { Urban }\end{array}$ & $\begin{array}{c}138 \\
92\end{array}$ & $\begin{array}{l}60.0 \\
40.0\end{array}$ \\
\hline $\begin{array}{l}\text { Level of education } \\
\text { Illiterate } \\
\text { Elementary } \\
\text { Secondary } \\
\text { Technical education } \\
\text { University } \\
\end{array}$ & $\begin{array}{l}49 \\
66 \\
15 \\
82 \\
18\end{array}$ & $\begin{array}{c}21.3 \\
28.7 \\
6.5 \\
35.7 \\
7.8 \\
\end{array}$ \\
\hline $\begin{array}{c}\text { Occupation } \\
\text { Employee } \\
\text { House wife }\end{array}$ & $\begin{array}{c}39 \\
191 \\
\end{array}$ & $\begin{array}{l}17.0 \\
83.0\end{array}$ \\
\hline $\begin{array}{c}\text { Socio economic classes } \\
\text { High } \\
\text { Middle } \\
\text { Low }\end{array}$ & $\begin{array}{c}34 \\
167 \\
29\end{array}$ & $\begin{array}{l}14.8 \\
72.6 \\
12.6\end{array}$ \\
\hline $\begin{array}{c}\text { Consanguinity } \\
\text { Yes } \\
\text { No }\end{array}$ & $\begin{array}{c}69 \\
161\end{array}$ & $\begin{array}{l}30.0 \\
70.0\end{array}$ \\
\hline $\begin{array}{c}\text { Body mass Index(BMI) } \\
\text { Mean } \pm \text { SD(range) }\end{array}$ & $28.45 \pm 5.11(1$ & \\
\hline
\end{tabular}

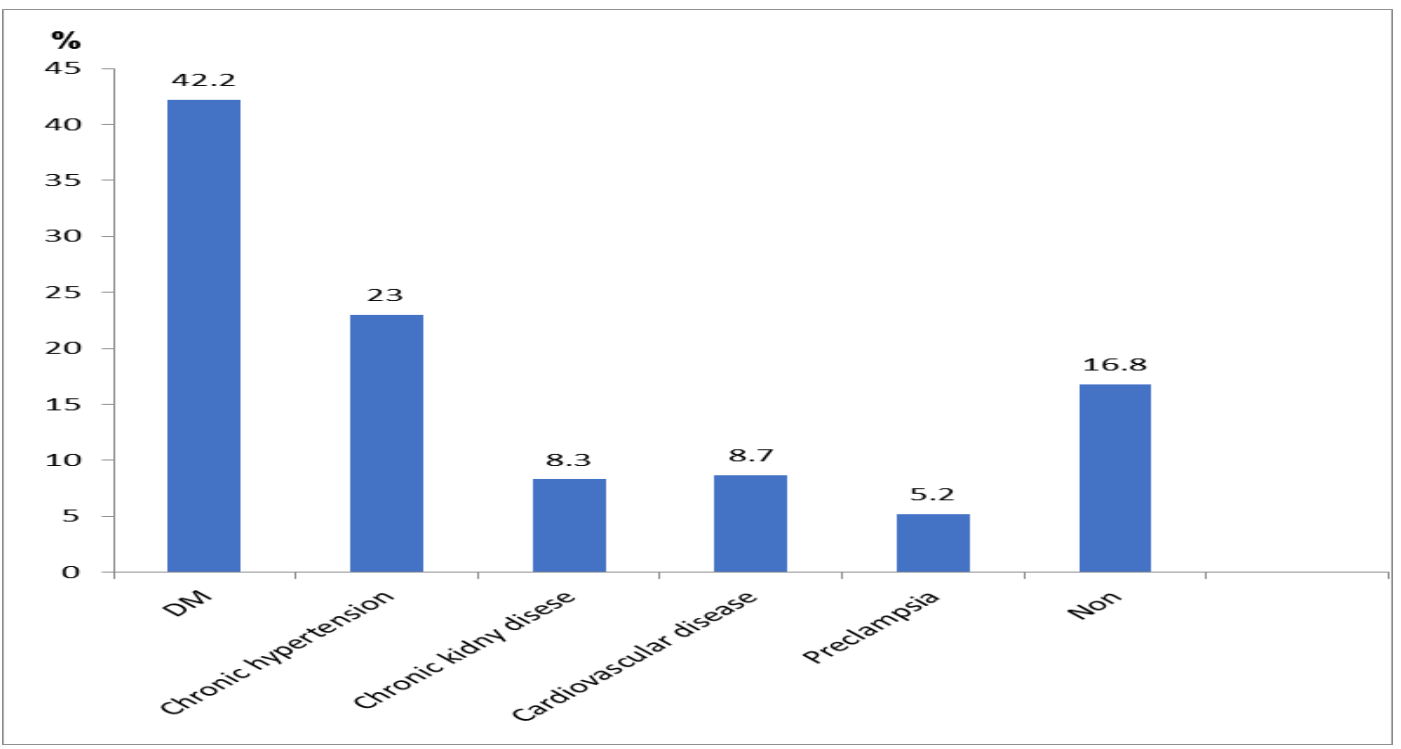

*More than one disease was selected

Fig. (1): Family history of chronic diseases and preeclampsia among studied pregnant women 
Table (2): Obstetrical history and chronic diseases of studied pregnant women

\begin{tabular}{|l|l|l|}
\hline \multicolumn{1}{|c|}{ Items } & No. $(\mathbf{n}=\mathbf{2 3 0})$ & \% \\
\hline Order of pregnancy & 39 & 17.0 \\
First & 54 & 23.4 \\
Second & 57 & 24.8 \\
Third & 80 & 34.8 \\
Fifth or more & & \\
Parity & 45 & 19.6 \\
Nullipara & 185 & 80.4 \\
Multipara & & 7.4 \\
\hline Women history of preeclampsia & 17 & 92.6 \\
Yes & 213 & 4.3 \\
No & 10 & 95.7 \\
\hline Previous excessive weight gain & 220 & 10 \\
Yes & & 90 \\
No & 23 & \\
\hline History of Chronic diseases & 207 & 47.8 \\
\hline Yes & & 26.1 \\
\hline No & 11 & 26.1 \\
\hline Chronic diseases(23) & 6 & 0 \\
Diabetes mellitus & 6 & \\
Chronic hypertension & 0 & \\
\hline Cardiovascular disease & & \\
\hline Chronic kidney diseases & & \\
\hline
\end{tabular}

Table (3): Distribution of the studied pregnant women according to the results of physical examination during current pregnancy.

\begin{tabular}{|c|c|c|c|c|c|c|c|c|c|c|c|}
\hline \multirow{2}{*}{$\begin{array}{c}\text { Items } \\
\text { Blood pressure }\end{array}$} & \multicolumn{2}{|c|}{$\begin{array}{l}\text { First contact: } \\
\quad(\mathbf{n}=\mathbf{2 3 0})\end{array}$} & \multicolumn{2}{|c|}{$\begin{array}{c}\text { First follow-up } \\
(n=230)\end{array}$} & \multicolumn{2}{|c|}{$\begin{array}{l}\text { Second follow- } \\
\text { up }(n=209)\end{array}$} & \multicolumn{2}{|c|}{$\begin{array}{c}\text { Third follow-up } \\
(n=201)\end{array}$} & $\begin{array}{c}\text { P- } \\
\text { value }^{1}\end{array}$ & $\begin{array}{c}\text { P- } \\
\text { value }^{2}\end{array}$ & $\begin{array}{c}\text { P- } \\
\text { value }^{3}\end{array}$ \\
\hline & No & $\%$ & No & $\%$ & No & $\%$ & No & $\%$ & \multirow{3}{*}{0.216} & \multirow{3}{*}{0.196} & 0.000* \\
\hline Normal & 229 & 99.6 & 225 & 97.8 & 205 & 98.1 & 172 & 85.6 & & & \\
\hline Hypertension & 1 & 0.4 & 5 & 2.2 & 4 & 1.9 & 29 & 14.4 & & & \\
\hline $\begin{array}{l}\text { Systolic BP: } \\
\text { Mean } \pm \text { SD } \\
\text { Range }\end{array}$ & \multicolumn{2}{|c|}{$\begin{array}{l}114.04 \pm 7.52 \\
90.0-150.0\end{array}$} & \multicolumn{2}{|c|}{$\begin{array}{l}115.48 \pm 8.49 \\
90.0-160.0\end{array}$} & \multicolumn{2}{|c|}{$\begin{array}{l}115.98 \pm 9.10 \\
90.0-160.0\end{array}$} & \multicolumn{2}{|c|}{$\begin{array}{l}121.24 \pm 18.16 \\
90.0-180.0\end{array}$} & $0.000 *$ & $0.000 *$ & 0.000* \\
\hline $\begin{array}{l}\text { Diastolic BP } \\
\text { Mean } \pm \text { SD } \\
\text { Range }\end{array}$ & \multicolumn{2}{|c|}{$\begin{array}{l}74.30 \pm 7.01 \\
60.0-120.0\end{array}$} & \multicolumn{2}{|c|}{$\begin{array}{c}75.04 \pm 6.85 \\
60.0-100.0\end{array}$} & \multicolumn{2}{|c|}{$\begin{array}{l}75.45 \pm 7.27 \\
60.0-100.0\end{array}$} & \multicolumn{2}{|c|}{$\begin{array}{c}79.25 \pm 13.60 \\
60.0-120.0\end{array}$} & 0.014* & $0.000 *$ & $0.000 *$ \\
\hline $\begin{array}{c}\text { Edema } \\
\text { Yes } \\
\text { No }\end{array}$ & $\begin{array}{c}\text { No } \\
0 \\
230\end{array}$ & $\begin{array}{c}\% \\
0.0 \\
100.0\end{array}$ & $\begin{array}{c}\text { No } \\
4 \\
226\end{array}$ & $\begin{array}{c}\% \\
1.7 \\
98.3\end{array}$ & $\begin{array}{c}\text { No } \\
4 \\
205\end{array}$ & $\begin{array}{c}\% \\
1.9 \\
98.1\end{array}$ & $\begin{array}{c}\text { No } \\
29 \\
172\end{array}$ & $\begin{array}{c}\% \\
14.4 \\
85.6\end{array}$ & 0.123 & $0.051^{*}$ & $0.000 *$ \\
\hline $\begin{array}{c}\text { Albumin } \\
\text { Yes } \\
\text { No }\end{array}$ & $\begin{array}{c}0 \\
230\end{array}$ & $\begin{array}{c}0.0 \\
100.0\end{array}$ & $\begin{array}{c}4 \\
226\end{array}$ & $\begin{array}{c}1.7 \\
98.3\end{array}$ & $\begin{array}{c}4 \\
205\end{array}$ & $\begin{array}{c}1.9 \\
98.1\end{array}$ & $\begin{array}{c}29 \\
172\end{array}$ & $\begin{array}{l}14.4 \\
85.6\end{array}$ & 0.123 & $0.051^{*}$ & $0.000 *$ \\
\hline
\end{tabular}

\section{Chi-square test}

$* P$-value ${ }^{1:}$ between first contact and first follow-up. $\quad * P$-value ${ }^{2:}$ between first contact and second follow-up.

*P-value ${ }^{3:}$ between first contact and third follow-up. 
No preeclampsia

83.9

Fig. (2): Current cases diagnosed with preeclampsia among studied pregnant women throughout the study phases of follow up.

Table (4): Distribution of studied pregnant women by outcomes of the current pregnancy.

\begin{tabular}{|c|c|c|}
\hline \multicolumn{1}{|c|}{ Items } & No. $\mathbf{( n = 2 3 0 )}$ & \% \\
\hline Fetal death(23) & 23 & 10.0 \\
Preeclampsia causes & 4 & 17.4 \\
Other causes & 19 & 82.6 \\
\hline Gestational age at delivery (n=207) & 20 & 9.7 \\
< 38 weeks & 97 & 46.9 \\
$38-<40$ weeks & 90 & 43.4 \\
$\geq 40$ weeks & $38.96 \pm 1.69(29.0-41.0)$ & \\
Mean \pm SD (Range) & 144 & 69.6 \\
CS & 63 & 30.4 \\
Vaginal & & \\
Modes of delivery: (n=207) & 199 & 96.1 \\
Flive & 8 & 3.9 \\
\hline Still birth & \multicolumn{2}{|c|}{} \\
\hline
\end{tabular}

Table (5): The relation between personal data and chronic diseases among studied pregnant women and developing of preeclampsia.

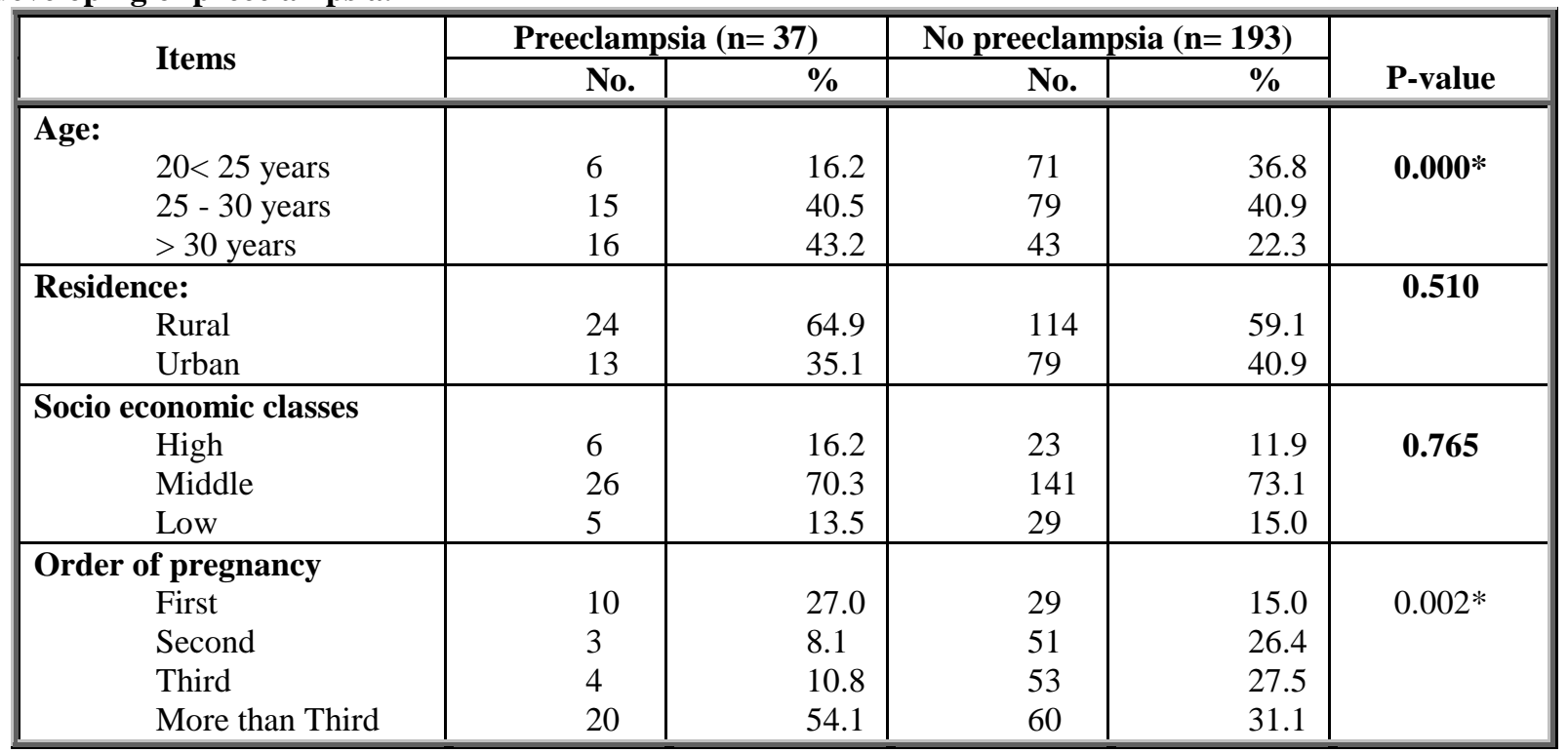




\begin{tabular}{|c|c|c|c|c|c|}
\hline \multirow{2}{*}{ Items } & \multicolumn{2}{|c|}{ Preeclampsia $(n=37)$} & \multicolumn{2}{|c|}{ No preeclampsia $(n=193)$} & \multirow[b]{2}{*}{ P-value } \\
\hline & No. & $\%$ & No. & $\%$ & \\
\hline $\begin{array}{c}\text { Previous preeclampsia } \\
\text { Yes } \\
\text { No }\end{array}$ & $\begin{array}{l}14 \\
23\end{array}$ & $\begin{array}{l}82.4 \\
10.8\end{array}$ & $\begin{array}{l}3 \\
190\end{array}$ & $\begin{array}{l}17.6 \\
89.2\end{array}$ & $0.000 *$ \\
\hline $\begin{array}{c}\text { Consanguinity } \\
\text { Yes } \\
\text { No } \\
\end{array}$ & $\begin{array}{l}10 \\
27 \\
\end{array}$ & $\begin{array}{l}27.0 \\
73.0\end{array}$ & $\begin{array}{l}59 \\
134\end{array}$ & $\begin{array}{l}30.9 \\
69.4\end{array}$ & 0.667 \\
\hline $\begin{array}{c}\text { Body mass index } \\
\text { Mean } \pm \text { SD }\end{array}$ & \multicolumn{2}{|c|}{$31.27 \pm 5.78$} & \multicolumn{2}{|c|}{$27.91 \pm 4.80$} & $0.001 *$ \\
\hline
\end{tabular}

Chi-square test, Fisher exact test

Statistical significant difference (0.05)

Table (6): Regressions analysis for prediction of preeclampsia risk factors among studied pregnant women.

\begin{tabular}{|l|c|c|c|c|}
\hline \multicolumn{1}{|c|}{ Risk factors } & \multirow{2}{*}{ OR } & \multicolumn{2}{c|}{ 95\% C.I. } & \multirow{2}{*}{ P-value } \\
\cline { 3 - 4 } & & Lower & Upper & 0.154 \\
\hline Maternal age & 1.076 & 0.973 & 1.191 & 0.821 \\
\hline Consanguinity & 1.104 & 0.469 & 2.600 & 0.951 \\
\hline Order of pregnancy $\left(\right.$ more than $\mathbf{3}^{\text {rd }}$ ) & 0.984 & 0.583 & 1.659 & $\mathbf{0 . 0 1 0}^{*}$ \\
\hline History of DM & $\mathbf{5 . 9 2 3}$ & 1.519 & 23.091 & $\mathbf{0 . 0 4 5}^{*}$ \\
\hline History of hypertension & $\mathbf{7 . 8 3 8}$ & 1.048 & 58.638 & \\
\hline
\end{tabular}

* Statistical significant difference, OR odds Ratio, CI Confidence interval

Table (1): Shows that $40.9 \%$ of the studied pregnant women aged from $25-30$ years, $60 \%$ of them were from rural areas and $35.7 \%$ of them had technical education. Also, this table revealed that $83 \%$ of the participants were house wives and $72.6 \%$ of them had middle socio-economic classes, while $30.0 \%$ of them had consanguinity. This table also reflects that body mass index mean \pm SD $28.4 \pm 5.11$.

Figure (1): Reflects that $42.2 \%$ of the studied pregnant women had family history of D.M. and $23.0 \%$ of them had family history of chronic hypertension, while $5.2 \%$ of them had family history of preeclampsia.

Table (2): Represents that $34.8 \%$ of the participants had order of pregnancy fifth or more, $80.4 \%$ of them were multipara, while $7.4 \%$ and $4.3 \%$ respectively of them had history of preeclampsia and previous excessive weight gain. According to mother's history of chronic diseases, this table illustrates that $4.8 \%$ of the studied pregnant women had D.M. and $2.6 \%$, $2.6 \%$ respectively of them had chronic hypertension and cardiovascular disease.

Table (3) Shows that there were highly statistical significant differences at $\mathrm{p}=0.000$ between first contact and $1^{\text {st }}, 2^{\text {nd }}$ and $3^{\text {rd }}$ follow-up for physical examination results of studied pregnant women (systolic and diastolic blood pressure). Regarding edema and albumin there are statistical significant differences between $1^{\text {st }}$ and $2^{\text {nd }}$ as well as between $1^{\text {st }}$ and $3^{\text {rd }}$ follow up.

Figure (2): Represents that $16.1 \%$ of the studied pregnant women were diagnosed with preeclampsia.
Table (4): Shows that $10 \%$ of the studied pregnant women previously aborted; the main cause of abortion among $17.4 \%$ of the study women was preeclampsia. Also, this table shows that $46.9 \%$ of the studied pregnant women gestational age at delivery ranged from 38 to less than 40 weeks, $69.6 \%$ of them delivered C.S., and $96.1 \%$ of them reported the pregnant outcome live baby.

Table (5): Illustrates that there are highly statistically significant differences between age, previous history of preeclampsia and developing of preeclampsia at $\mathrm{P}$ $=0.000$, also between body mass index, order of pregnancy, D.M. and hypertension with developing preeclampsia $(\mathrm{P}=0.001,0.002,0.003$ and 0.007$)$ respectively

Table (6): Illustrates the regression analysis which included five factors: Three factors were not significant $\{$ maternal age $(\mathrm{P}-\mathrm{value}=0.154$, $\mathrm{OR}=1.076)$, consanguinity $\quad(\mathrm{P}$-value $=0.821$, $\mathrm{OR}=1.104)$, order of pregnancy $\left(3^{\text {rd }}\right.$ or more) $(\mathrm{P}-$ value $=0.951, \quad \mathrm{OR}=0.984)\}$, two factors were significant \{history of DM (P-value $=0.010$, $\mathrm{OR}=5.923)$ and history of hypertension (P-value= $0.045, \mathrm{OR}=7.838$ )

\section{Discussion}

Preeclampsia has remained a significant public health threat in both developed and developing countries contributing to maternal and perinatal morbidity and mortality globally. Preeclampsia affects approximately $3-14 \%$ of all pregnancies worldwide. The identification of predisposing risk factors for the 
development of preeclampsia could lead to a better understanding of the causality and pathogenesis of this challenging and high-risk disorder (Endeshaw et al., 2014, Cheng et al., 2016 \& Chrelias et al., 2016).

The present study aimed to predict causing risk factors of preeclampsia at ANC in Assiut Women Health Hospital.

The present study showed that more slightly than two fifth of participated women aged 25-30 years, the majority of them were house wives and less than three quarter of the studied pregnant women belonged to middle class of socioeconomic class. The current study agreed with Jašović-Siveska et al., (2011a) who conducted a study to "predict the mild and severe preeclampsia with blood pressure measurements in the first and the second trimester of pregnancy" in Macedonia and reported that the age group of participated women ranged from 25-30 years old which represents two fifths of the total study sample. Also the current study was in the same line with Endeshaw et al., (2014) \& Essam et al., (2011) who conducted a study to measure "Risk factors and their impacts of preeclampsia among pregnant mothers in Egypt" and they recorded that more than one fifth of the participant's age group ranged from 26-30 years old.

Also, this result congruent with Khader et al., (2017) who conducted a study "Preeclampsia in Jordan: incidence, risk factors, and its associated maternal and neonatal outcomes" and reported that the majority of participated women were house wives. Also the same finding of Essam et al., (2011).

The present study showed that less than one third of the pregnant women were married from their relatives, and it disagreed with Kashanian et al., (2011) who conducted a study entitled " Risk factors for pre-eclampsia: a study in Tehran, Iran " and found that consanguinity present in only $(6.4 \%)$ of their study sample. This result reflects the rooted beliefs and concepts about consanguinity marriage especially in Upper Egypt community.

This study also, revealed that more than two fifths of the study sample had family history of D.M. and $47.8 \%$ of them had D.M. This result is disagreement with Chrelias et al., (2016), who conducted a study entitled "Serum inhibin and leptin: Risk factors for preeclampsia?" and reported that D.M was present only in $8.2 \%$ of the participated women, and disagrees with Budhram, (2015) who conducted a study entitled "A prospective study evaluating the association of specific risk factors with the development of preeclampsia", and reported the D.M was $13.4 \%$.

The present study showed that only $26.1 \%$ of the studied pregnant women had history of hypertension, in contrast with Macdonald-Wallis et al., (2015) who studied "Antenatal blood pressure for prediction of preeclampsia, preterm birth and small for gestational age babies: development and validation in two general population cohorts" and reported that $15.3 \%$ of the participants had a history of gestational hypertension.

Concerning to the number of parity of pregnant women, the finding of the present study illustrated that about one fifth of the studied women were nulliparous. This result agreed with Budhram, (2015), who observed that more than one fifth $(23 \%)$ were nulliparous women.

In the light of the current result only, $5.2 \%$ of the studied pregnant women had family history of PE, and $7.4 \%$ of them had previous history of PE. This result agrees with Essam et al., (2011), who reported that only $4 \%$ of women had family history of PE and Luo \& Ma, (2013) who conducted a study to assess "Risk factors for preeclampsia" and found that 11.1\% of the participants had history of preeclampsia.

Concerning measuring the blood pressure from the beginning of the pregnancy and knowing the values of the artery pressure in the period within 20 weeks, the values of mean arterial blood pressure over 85-90 $\mathrm{mmHg}$ and values of diastolic blood pressure over $75 \mathrm{mmHg}$ are important predictive indicator for determination the risk of hypertensive disorders in pregnancy, especially PE (Duckitt \& Harrington, 2011) In the present study the evaluation of blood pressure started as early as 14 weeks of gestation which is very important in discovering PE in early stages. According to measuring systolic and diastolic blood pressure during first contact and following up, this study revealed that there is a highly statistical significant difference between first contact and three times follow up at $\mathrm{P}=0.000$. Likewise, the other same finding recorded by Jašović-Siveska et al., (2011a) \& Hassan et al., (2015) who studied "The role of risk assessment at antenatal care clinics in the prediction of preeclampsia in a High-Altitude Area" at Maternity and Pediatric Hospital in Saudi Arabia and found that there is a statistical significant difference between hypertensive studied pregnant women and development of PE during pregnancy. This study also was consistent with the findings of Siddiqui et al., (2011) who studied "Iron Status Parameters in Preeclamptic Women" who reported that a mean systolic BP was $143.1 \pm 7.8 \mathrm{mmHg}$ versus $125.1 \pm 19.6 \mathrm{mmHg}$ and mean diastolic BP was $94.3 \pm 4.9 \mathrm{mmHg}$ versus $78 \pm 13.3 \mathrm{mmHg}$ in the preeclamptic and control groups, respectively $(\mathrm{P}<$ $0.05)$.

The global incidence of PE has been estimated at 5$14 \%$ of all pregnancies, while in developing nations the incidence of the disease ranges from $4-18 \%$. The 
prevalence of PE in developing countries has been estimated between $1.8 \%$ and $16.7 \%$ (Osungbade \& Ige, 2011, \& Imaralu et al., 2015). The present study revealed that $16.1 \%$ of studied pregnant women had PE. This result agrees with Guerrier et al., (2013) who studied "Factors associated with severe preeclampsia and eclampsia in Jahun, Nigeria", and reported that $(16 \%)$ of pregnant women had PE. This result reflects poor seeking behaviors and unavailability of health care service and trained personal because three fifth of the studied pregnant women were from rural areas.

Regarding to the gestational age at delivery, the result of the present study revealed that the mean of gestational age at delivery were $38.96 \pm 1.69$ weeks. This result agrees with Honigberg et al., (2016) who conducted a study about " Analysis of changes in maternal circulating angiogenic factors throughout pregnancy for the prediction of preeclampsia", in which mean of gestational age at delivery were 38.9 \pm 1.8 weeks ,while it disagreed with Agrawal \& Maitra, (2016) who conducted a study about "Prediction of adverse maternal outcomes in preeclampsia using a risk prediction model", and reported that mean of gestational age at delivery were $34.4 \pm 4.2$ weeks.

According to abortion and its causes among pregnant women during current pregnancy, the present study shows that $10 \%$ of the studied pregnant women had abortion, the main cause of abortion in $17.4 \%$ of them, was preeclampsia. This result is in agreement with Jasovic-Siverska et al., (2011a) who reported that abortion is associated with Pregnancy-Induced Hypertension.

Concerning to the outcome of pregnancy, the current study found that more than two third of the pregnant women had caesarean section delivery and $3.9 \%$ of them had still birth. This finding was incongruent with Gupta et al., (2017) who conducted a study "Prediction of Preeclampsia in Early Pregnancy by Estimating the Spot Urinary Albumin/Creatinine Ratio" and reported that slightly more than one fifth $(21.4 \%)$ of the pregnant women were had caesarean section delivery. This result also disagreed with AlRukeimi et al., (2014), who shows that only (0.6\%) of the fetuses were stillbirth. This result may be due to fear of labor pain.

Risk factors associated with PE include: nulliparity, obesity, multiple gestation, family history of PE or eclampsia, preexisting hypertension or renal disease, previous PE or eclampsia, diabetes mellitus, nonimmune hydrops, antiphospholipid antibody syndrome, age 35 years or older. It is extremely rare for preeclampsia to develop before 20 weeks gestation, but when it does occur it is usually associated with renal disease or molar pregnancy
(Sibai, 2010) The present study showed that there were statistically significant differences between maternal age and developing of preeclampsia ( $p$ $=0.000)$, and also revealed that PE is most common developing among multi gravida (four or more pregnancy) studied pregnant women, This study disagrees with a previous study done by JasovicSiverska, et al., (2011b) about "Previous pregnancy history, parity, maternal age and risk of pregnancy induced hypertension" who concluded that PE is most common developed in young primiparas and older multiparas.

This result illustrated that $\mathrm{PE}$ is more developed among pregnant women from rural area (more than three fifth) than from urban area (more than one third) which is due to negative behavior for seeking of care and lack of health care facilities and well trained personal in rural areas. Also, there are statistically significant differences between body mass index and developing of preeclampsia ( $\mathrm{P}$ $=0.001$ ), this finding was matching with MacdonaldWallis et al., (2015), who found that there is a positive relationship between overweight and developing of PE.

Furthermore, the current study corresponds with the findings of the study by Hassan et al., (2015) who found that there are highly statistically significant differences between overweight and developing of $\mathrm{PE}$ in pre-eclamptic group than in the control group. Also, there are statistically significant differences between maternal previous preeclampsia and DM and hypertension $(\mathrm{p}=0.000)$. This finding matches with Shiozaki, et al., (2017) who studied "Prenatal risk assessment of gestational hypertension and preeclampsia using clinical information" in Japan who found that DM in that study was one of risk factor for developing PE. Additional consider history of hypertension as a risk factor for pervious studied done by Bartsch et al., (2016) about "Clinical risk factors for pre-eclampsia determined in early pregnancy", who reported hypertension as risk factors for preeclampsia.

\section{Conclusion}

Based on the results of the present study, it can be concluded multiple risk factors are predicting preeclampsia such as diabetes, hypertension for pregnant women, previous $\mathrm{PE}$, family history of (diabetes, hypertension and preeclampsia), obesity and age of mother which can be used as a preventing tool of preeclampsia. The total percent diagnosed with preeclampsia was $16.1 \%$.

History of DM and hypertension was the predictor in the final model among pregnant women who diagnosed with preeclampsia for DM and hypertension. 


\section{Recommendation}

Based on the results, the present study recommended

- Health education during premarital examination for all females and pregnant women about risk factors of PE.

- Addressing Ministry of Health to improve prenatal services including screening of PE.

- Provide counseling for pregnant women who had previous preeclampsia.

- Health education during home visits for all women about preeclampsia risk factors.

\section{References}

1. Abd El-twab A., (2012): Socioeconomic scale, Faculty of Education, Assiut University.

2. Abubakar A., Abdullahi R., Jibril H., Dauda M., \& Poopola M., (2009): Maternal ethnicity and severity of preeclampsia in Northern Nigeria. Asian Journal of Medical Sciences,1(3), 104107.?

3. Agrawal S., \& Maitra N., (2016): Prediction of adverse maternal outcomes in preeclampsia using a risk prediction model. The Journal of Obstetrics and Gynecology of India, 66(1), 104-111.

4. Al-Jameil N., Aziz K., Fareed K., \& Tabassum H., (2014): "A brief overview of preeclampsia". Journal of clinical medicine research 6 (1): 1-7.

5. Al-Rukeimi A., Al-Haddad A., \& Adam I., (2014): Risk factors for pre-eclampsia, eclampsia, and associated adverse outcomes in Hajjah, Yemen. Int J Gynaecol Obstet, 127, 91-92.

6. American College of Obstetricians and Gynecologists (ACOG), (2013): Hypertension in pregnancy. Report of the American college of obstetricians and gynecologists' task force on hypertension in pregnancy. Obstetrics and gynecology, 122(5), P1122.

7. Bartsch E., Medcalf K., Park A., \& Ray J., (2016): Clinical risk factors for pre-eclampsia determined in early pregnancy: systematic review and meta-analysis of large cohort studies. BMJ, 353, i1753.m

8. Brice no-P'erez C., Brice no-Sanabria L., \& Vigil-De Gracia P., (2009): "Prediction and prevention of preeclampsia," Hypertension in Pregnancy, 28, (2), 138-155.

9. Brown M., Best K., Pearce M., Waugh J., Robson S., \& Bell R., (2013): Cardiovascular disease risk in women with pre-eclampsia: systematic review and meta-analysis. European journal of epidemiology, 28(1):1-19.

10. Budhram, S., (2015): A prospective study evaluating the association of specific risk factors with the development of preeclampsia (Doctoral dissertation, Stellenbosch: Stellenbosch University) 25(2:4-7.

11. Cheng P., Huang S., Su S., Hsiao C., Peng H., \& Duan T., (2016): Prognostic value of cardiovascular disease risk factors measured in the first-trimester on the severity of preeclampsia. Medicine, 95(5).

12. Chrelias G., Makris G., Papanota A., Spathis A., Salamalekis G., Sergentanis T., (2016): Serum inhibin and leptin: Risk factors for preeclampsia?. Clinica Chimica Acta, 463, 84-87.

13. Direkvand-Moghadam A., Khosravi A., \& Sayehmiri K., (2012): Predictive factors for preeclampsia in pregnant women: a unvariate and multivariate logistic regression analysis. Acta Biochim Pol, 59(4), 673-7.

14. Duckitt K., Harrington D., (2011): Risk factors for preeclampsia at antenatal booking: systematic review of controlled studies. BMJ., 330, 565.

15. Endeshaw M., Ambaw F., Aragaw A., \& Ayalew A., (2014): Effect of maternal nutrition and dietary habits on preeclampsia: a case-control study. International Journal of Clinical Medicine, 5(21), 1405.

16. Essam A., Khalifa H., Amer S., \& Mohammed K., (2011): Risk Factors and Impacts of PreEclampsia: An Epidemiological Study among Pregnant Mother in Egypt. Journal of American Science; 7(5):311.

17. Gaccioli F., Lager S., Sovio U., CharnockJones S., \& Smith G., (2017): The pregnancy outcome prediction (POP) study: Investigating the relationship between serial prenatal ultrasonography, biomarkers, placental phenotype and adverse pregnancy outcomes. Placenta, 59, S17-S25.

18. Guerrier G., Oluyide B., Keramarou M., \& Grais R., (2013): Factors associated with severe preeclampsia and eclampsia in Jahun, Nigeria, International Journal of Women's Health 5, 509513.

19. Gupta, N., Gupta, T., \& Asthana, D., (2017): Prediction of Preeclampsia in Early Pregnancy by Estimating the Spot Urinary Albumin/Creatinine Ratio. The Journal of Obstetrics and Gynecology of India, 67(4), 258-262.

20. Hassan B., Almushait M., Mubashar H., \& Zia S., (2015): The Role of risk assessment at antenatal care clinics in the prediction of preeclampsia in a High Altitude Area. International Journal of Clinical Medicine, 2016, 7, 10-15

21. Hofmeyr, G., Lawrie, T., Atallah, Á., Duley, L., \& Torloni, M., (2014): Calcium supplementation during pregnancy for preventing hypertensive 
disorders and related problems. The Cochrane Database Systematic Review, 8(8).

22. Honigberg M., Cantonwine D., Thomas A., Lim K., Parry S., \& McElrath T., (2016): Analysis of changes in maternal circulating angiogenic factors throughout pregnancy for the prediction of preeclampsia. Journal of Perinatology, 36(3), 172

23. Imaralu J., Olaleye A., Badejoko O., Loto O., \& Ogunniyi S., (2015): The use of magnesium sulphate (MgSO 4) for seizure prophylaxis: clinical correlates in a Nigerian tertiary hospital. International Journal of Medicine and Biomedical Research, 4(2), 72-81.

24. Jasovic-Siveska, Emiija, \& Jasovic V., (2011):a Prediction of mild and severe preeclampsia with blood pressure measurements in first and second trimester of pregnancy. Ginekologia polska, 82(11).

25. Jasovic-Siveska E., Jasovic V., \& Stoilova S., (2011) b: Previous pregnancy history, parity, maternal age and risk of pregnancy induced hypertension. Bratisl Lek Listy, 112(4), 188-191.

26. Jasovic-Siveska E., (2013): Preeclampsia: Should be Predict and Prevent? Reproductive System Sexual Disorders 3: e113.

27. Kashanian M., Baradaran H., Bahasadri S., \& Alimohammadi R., (2011): Risk factors for preeclampsia: a study in Tehran, Iran. Archives of Iranian medicine, 14(6), 412.

28. Kenny L., Black M., \& Poston L., (2014): Early pregnancy prediction of preeclampsia in nulliparous women, combining clinical risk and biomarkers: the screening for pregnancy endpoints (SCOPE) international cohort study. Hypertension 2014; 64:644-52.

29. Khader Y., Batieha A., Al-njadat R., \& Hijazi S., (2017): Preeclampsia in Jordan: incidence, risk factors, and its associated maternal and neonatal outcomes. The Journal of Maternal-Fetal \& Neonatal Medicine, 1-7.

30. Khanum S., de Cassia Teixeira Rangel R., de Lourdes de Souza M., Raduenz Huf Souza A., \& Naz N., (2015): "Maternal Mortality related to Pre-eclampsia/Eclampsia in Santa Catarina, Brazil: A Population-based Study", Athens: ATINER'S Conference Paper Series, No: NUR2015-1769.

31. Kharaghani R., Cheraghi Z., Okhovat Esfahani B., Mohammadian Z., \& Nooreldinc R., (2016): Prevalence of Preeclampsia and Eclampsia in Iran. Archives of Iranian Medicine, 19(1), 64-71.

32. Leslie K., Thilaganathan B., \& Papageorghiou A., (2011): Early prediction and prevention of pre-eclampsia, Best Practice \&Research Clinical Obstetrics \& Gynecology, 25(3), 343-354.

33. Luo B., \& Ma X., (2013): Risk factors for preeclampsia: a case-control study. Hypertension in pregnancy, 32(4), 432-438.

34. Macdonald-Wallis, C., Silverwood R., De Stavola, B., Inskip H., Cooper C., Godfrey K., \& Tilling K., (2015): Antenatal blood pressure for prediction of preeclampsia, preterm birth, and small for gestational age babies: development and validation in two general population cohorts. BMJ, 351, h5948.

35. Munirathnamma M., \& Lakshmamma T., (2013): Knowledge of Staff Nurses Regarding Management of Pregnancy Induced Hypertension (PIH).? International Journal of Humanities and Social Science Invention ISSN 2(11), 8-12.

36. National institute for health \& clinical excellence, (2012): hypertension in pregnancy,pp10-15.

37. North R., McCowan L., \& Dekker G., (2011): Clinical risk prediction for pre-eclampsia in nulliparous women: development of model in international prospective cohort," British Medical Journal, 342(7803), 1875.

38. Osungbade K., \& Ige O., (2011): Public health perspectives of preeclampsia in developing countries: implication for health system strengthening. Journal of pregnancy, 56-60.

39. Poon L., Kametas N., Chelemen T., Leal A., \& Nicolaides K., (2010): "Maternal risk factors for hypertensive disorders in pregnancy: a multivariate approach," Journal of Human Hypertension, 24(2), 104-110.

40. Poon L., \& Nicolaides K., (2014): Early prediction of preeclampsia. Obstetrics and gynecology international, 20(11).

41. Salam R., Das J., Ali A., Bhaumik S., \& Lassi Z., (2015): Diagnosis and management of preeclampsia in community settings in low and middle-income countries. Journal of family medicine and primary care, 4(4), 501.

42. Seed P., Chappell L., Black M., Poppe K., Hwang Y., \& Kasabov N., (2011): Prediction of preeclampsia and delivery of small for gestational age babies based on a combination of clinical risk factors in high-risk women. Hypertension in pregnancy, 30(1), 58-73.

43. Shiozaki A., Tanaka T., Ito M., Sameshima A., Inada K., Yoneda N., \& Saito S., (2017): Prenatal risk assessment of gestational hypertension and preeclampsia using clinical information. Hypertension Research in Pregnancy, 4(2), 74-87.

44. Sibai B., (2010): Preeclampsia. In J. T. Queenan, J. Hobbins \& C. Y. Spong (Eds.), Protocols for 
HighRisk Pregnancies (5th ed.). West Sussex, UK: Wiley-Blackwell, 12(6).

45. Sidani M., \& Siddik S., (2011): Preeclampsia, a new perspective in 2011. Middle East Journal of Anesthesiology, 21, 207-14.

46. Siddiqui I., Jaleel A., Kadri H., Saeed W., \& Tamimi W., (2011): Iron Status Parameters in Preeclamptic Women. Archives of Gynecology and Obstetrics, 284, 587-591.

47. Thadhani R., Hagmann H., Schaarschmidt W., Roth B., Cingoez T., \& Karumanchi S., (2016): Removal of Soluble Fms-Like Tyrosine Kinase-1 by Dextran Sulfate Apheresis in Preeclampsia. Journal American Society Nephrology, 27(3), 903-913.

48. World Health Organization (WHO), (2005): Make every mother and child count, the world health report, Geneva, Switzerland. 